\title{
Roles of circulating endothelial progenitor cells and endothelial cells in gastric carcinoma
}

\author{
BOJING LI $^{1^{*}}$, ZHIHONG NIE $^{1^{*}}$, DENGHAI ZHANG $^{2}$, JIAN WU $^{3}$, BIN PENG $^{2}$, XIAOYAN GUO $^{1}$, \\ YIHAI SHI ${ }^{1}$, XIAOYAN CAI ${ }^{4}$, LIMIN XU $^{5}$ and FANFAN CAO ${ }^{2}$ \\ ${ }^{1}$ Department of Gastroenterology; ${ }^{2}$ Sino-French Cooperative Central Laboratory; Departments of \\ ${ }^{3}$ Pathobiology, ${ }^{4}$ General Surgery and ${ }^{5}$ Laboratory Medicine, Shanghai Gongli Hospital, \\ Secondary Military Medical University, Shanghai 200135, P.R. China
}

Received November 17, 2015; Accepted September 7, 2017

DOI: $10.3892 / \mathrm{ol} .2017 .7272$

\begin{abstract}
The present study aimed to investigate the role of endothelial progenitor cells (EPCs) and endothelial cells (ECs) in the peripheral blood of patients with gastric cancer (GC), and to investigate vascular endothelial growth factor (VEGF) expression and microvessel density (MVD) in GC tissues. First, $6 \mathrm{ml}$ peripheral blood with added anticoagulant was collected from each of the 42 patients with $\mathrm{GC}$, followed by determination of the number of EPCs and ECs by flow cytometry using the surface markers cluster of differentiation (CD) $34^{\text {bright }} \mathrm{CD} 133^{+} \mathrm{CD} 31^{+} \mathrm{CD} 45^{\text {dim }}$ and CD34 ${ }^{\mathrm{dim}} \mathrm{CD} 133^{-} \mathrm{CD} 31^{\text {bright }} \mathrm{CD} 45^{-}$, respectively. VEGF expression in patients with GC was detected by the streptomycin avidin-peroxidase immunohistochemical method, and MVD was calculated using the marker CD34. EPC and EC levels were positively associated with VEGF expression level, as well as with MVD. VEGF expression was positive in $66.67 \%$ GC cases, and its level was significantly associated with tumor-node-metastasis (TNM) stage, invasion depth and lymph-node metastasis $(\mathrm{P}<0.05)$. VEGF expression level was also positively associated with MVD. MVD in GC was significantly larger than that in normal tissue $(\mathrm{P}<0.01)$, and it was significantly associated with TNM stage $(\mathrm{P}<0.05)$, invasion depth $(\mathrm{P}<0.01)$ and lymph-node metastasis $(\mathrm{P}<0.01)$. EPCs in
\end{abstract}

Correspondence to: Dr Limin Xu, Department of Laboratory Medicine, Shanghai Gongli Hospital, Secondary Military Medical University, 219 Miao Pu Road, Pudong, Shanghai 200135, P.R. China E-mail: 13564378807@163.com

Dr Fanfan Cao, Sino-French Cooperative Central Laboratory, Shanghai Gongli Hospital, Secondary Military Medical University, 219 Miao Pu Road, Pudong, Shanghai 200135, P.R. China

E-mail: 13636331380@163.com

*Contributed equally

Key words: gastric cancer, neovascularization, endothelial progenitor cells, endothelial cells, vascular endothelial growth factor, microvessel density the peripheral blood have an important role in GC development, and may be a promising indicator of GC diagnosis and prognosis.

\section{Introduction}

Gastric cancer (GC) is one of the most common types of malignant tumors of the digestive system (1). Among the incident diagnosed cases of cancer each year, GC ranked fourth, and ranked third in cancer-associated mortalities in 2015 (1). Although the global incidence of GC has declined slightly, it remains one of the most common malignant tumors in China, with no notable decrease in mortality. The reason may be attributed to the low early diagnosis rate of $\sim 10 \%$ (the majority of stomach cancer cases are diagnosed at late stage) and the low 5-year survival rate (7-34\%), leading to high morbidity and mortality rates (2). There is currently an urgent requirement to improve the survival rate of advanced GC.

Folkman (3) first confirmed that 'both tumor growth and metastasis are dependent on angiogenesis'. In 1997, Asahara et al (4) isolated cluster of differentiation (CD) $34^{+} /$vascular endothelial growth factor receptor (VEGFR)-2+ endothelial progenitor cells (EPCs) from peripheral blood by magnetic-activated cell sorting. EPCs are the precursor cells of endothelial cells (ECs), which have a stronger proliferative capacity compared with mature ECs and are involved in tumor angiogenesis (5). It is recognized that EPCs are initially primarily present in the bone marrow, where they express CD34, CD133 (AC133) and kinase domain insert receptor (KDR; also termed VEGFR-2 or Flk-1), but no CD144 (vascular endothelial-cadherin) or Von Willebrand factor (vWF). Following the release of EPCs into the peripheral blood, CD133 is not expressed, CD34 expression is gradually reduced and expression of KDR continues (6). This is associated with several mature EC markers, including CD144, CD31, vWF and endothelial nitric oxide synthase, as well as low density lipoprotein and Ulex europaeus agglutinin-1 (7). The identification of $\mathrm{vWF}$ may be a landmark of the differentiation of EPCs into mature ECs (7).

Tumor growth, invasion and metastasis depend on the formation of new tumor blood vessels, occurring by vasculogenesis and angiogenesis (8). The former refers to the 
in situ differentiation of EPCs into blood vessels, while the latter refers to the formation of new blood vessel branches and capillary plexus from the existing blood vessels via budding (8). The two processes are complementary. Tumor growth requires blood vessels to maintain tumor cells; tumor volume is usually $<3 \mathrm{~mm}^{3}$ when lacking new blood vessels (9). Only tumors completing vascularization can achieve a rapid increase in cell number and volume (10). The stomach has abundant blood vessels, thus providing a good material foundation for tumor growth, metastasis and invasion. Therefore, studies on angiogenesis are necessary for understanding the growth, metastasis, tumor infiltration and prognosis of gastric cancer.

Formation of tumor blood vessels is a continuous, uncontrolled and complex multi-step process, including capillary basement membrane degradation, endothelial cell migration, proliferation, formation of a tubular structure, basement membrane formation and blood flow patency, which is regulated by angiogenesis-promoting factors and angiogenesis inhibitory factors (11). Thus far, over 30 types of angiogenic factors have been reported, and VEGF, considered the most important and potent one among them, can promote the division, proliferation, migration and vascular construction of ECs in vivo (12). VEGF is highly expressed in numerous types of malignant tumors such as ovarian and prostatic cancer and gastrointestinal adenocarcinomas (13-15), and its overexpression is considered to be associated with increased angiogenesis, proliferation and metastasis $(16,17)$.

Tumor angiogenesis can be assessed quantitatively by microvessel density (MVD), which is calculated as the number of microvessels per unit area using specific antibodies (such as VIII factor antibody, CD31 and CD34) to label vascular ECs by an immunohistochemical method (18). CD34 is the most sensitive tumor blood vessel marker. Numerous malignant tumors have a significantly larger MVD when compared with normal tissue, and tumors with a higher MVD are also prone to metastasis, recurrence and poor prognosis (19). MVD has become an important indicator for forecasting tumor metastasis, recurrence and prognosis (20). It has been reported that MVD is a good indicator of prognosis in gastric cancer, particularly for early-stage gastric cancer. VEGF and MVD can be prognostic factors for GC (21). Kido et al (22) investigated VEGF expression in GC tissues, and showed that high expression of VEGF is associated with poor prognosis. In addition, they identified that the VEGF-positive tissues have a significantly larger MVD value compared with VEGF-negative tissues.

A previous study demonstrated that EPCs are more likely to be involved in tumor angiogenesis than in common granulation tissue- and growth factor-mediated angiogenesis, which can account for 5-25\% of new blood vessels in common tissues, and as much as $35-45 \%$ in tumors (16). Whether growth, metastasis and invasion of gastric tumor cells depend on EPC mobilization and incorporation into the tumor vasculature has not yet been elucidated. In the present study, through measuring the number of EPCs and ECs in the peripheral blood of patients with GC, detecting VEGF expression and calculating MVD value in GC tissue, the association between either EPCs or ECs and tumor growth, angiogenesis, invasion and metastasis was investigated, aiming to provide a basis for GC diagnosis, prognosis and targeted therapy.

\section{Materials and methods}

Patients and clinicopathological classification. Between December 2008 and March 2011, a total of 42 patients with GC confirmed by pathological examination who were subject to surgical resection at Shanghai Gongli Hospital were recruited in the present study (approved by the Ethical Committee of Shanghai Gongli Hospital, Secondary Military Medical University, Shanghai, China). Written informed consent was obtained from each patient prior to the study. Patients were excluded if they met any of the following criteria: Diagnosis with any other severe syndrome, such as upper gastrointestinal bleeding and diffuse peritonitis; taking non-steroidal anti-inflammatory drugs, corticosteroids or statins; history of acute myocardial infarction, angina pectoris, limb ischemia, trauma or surgery; or if the patient had received chemotherapy and radiotherapy. Finally, 42 patients with GC, with a mean age of 55.2 \pm 1.8 years, including 28 males $(66.7 \%)$ and 14 females $(33.3 \%)$ were enrolled. The tumor size and depth $(\mathrm{T})$ of primary lesion, and lymph node metastasis status (N) were determined by a pathologist, and whether there was a distant metastasis (M) was determined by pathological examination. The tumor diameter was $<5 \mathrm{~cm}$ in 29 cases and $\geq 5 \mathrm{~cm}$ in 13 cases. Tumors had not invaded into the serosa in 11 cases and had penetrated into the serosa in 31 cases. Tumors were highly differentiated in 14 cases, moderately differentiated in 15 cases and poorly differentiated in 13 cases. Local lymph node metastasis was detected in 20 cases and not in 22 cases, while distant metastasis was detected in 8 cases and not in 34 cases. According to the tumor-node-metastasis (TNM) staging system developed by the Union for International Cancer Control (6th edition; 2002) (23), 9 cases were at stage I, 15 cases at stage II, 10 at stage III and 8 cases at stage IV. The normal gastric tissues adjacent to gastric tumor tissue were also collected as a control. All the pathological specimens were fixed in $10 \%$ neutral formalin at room temperature overnight once collected.

Immunohistochemical staining and scoring. For tissues collected from each case, one paraffin-embedded section was prepared for routine hematoxylin and eosin (H\&E) staining, and the rest were used for immunohistochemical staining.

All the collected tissues were first fixed in $10 \%$ neutral formalin at room temperature overnight, embedded in paraffin and finally prepared into $4-\mu \mathrm{m}$ thick serial sections. Subsequently, the sections were heated at $60^{\circ} \mathrm{C}$ for $60 \mathrm{~min}$, and then were dewaxed using xylene (purity, >95\%) twice for 10 min each time, following by de-benzolization and hydration in serial alcohol for 5 min $(100,95,80$ and 70\%). H\&E staining was performed as follows: The sections were stained with $0.5 \mathrm{~g} / 100 \mathrm{ml}$ of hematoxylin for $10 \mathrm{~min}$ to stain the nuclei at room temperature, followed by color separation using $1 \%$ hydrochloric acid solution and $1 \%$ ammonia for $5 \mathrm{sec}$. Subsequent to washing under tap water for $1 \mathrm{~h}$, the sections were briefly immersed in distilled water, followed by dehydration in 70 and $90 \%$ ethanol successively for $10 \mathrm{~min}$ each, followed by cytoplasmic staining using ethanol eosin $(0.5 \mathrm{~g} / 100 \mathrm{ml})$ for $3 \mathrm{~min}$ at room temperature. Finally, the stained sections were dehydrated using absolute ethyl alcohol, xylene clearing and mounting. When the gum became somewhat dry, the sections were labelled. VEGF and CD34 expression in gastric 
carcinoma and normal gastric tissues was detected by the streptomycin avidin-peroxidase (SP) method using S-P kits (Fuzhou Maixin Biotech Co., Ltd., Fuzhou, China) following the manufacturer's protocol (24). Primary rabbit anti-human monoclonal antibody against VEGF (cat. no. MAB-0243; Fuzhou Maixin Biotech Co., Ltd.) was diluted 100 times, and was incubated at the room temperature for 60 min with known colorectal cancer-positive sections as a positive control. In addition, primary mouse anti-human antibody against CD34 (cat. no. MAB-0034-P, Fuzhou Maixin Biotech Co., Ltd.) was diluted 200 times, and was incubated at $4^{\circ} \mathrm{C}$ overnight. Known GC-positive sections were used as a positive control, and PBS buffer instead of primary antibody was used for the negative control. Subsequently, $50 \mu \mathrm{l}$ of biotin labeling sheep anti-rabbit or rabbit anti-mouse secondary antibodies (cat. no. KIT-9706 or KIT-9710; 1:1,000; Fuzhou Maixin Biotech Co., Ltd.) were added into the above sections at the room temperature for 10 min, respectively. Finally, VEGF and CD34-positive cells in the sections were stained using $100 \mu \mathrm{l}$ DAB for 3-10 min at room temperature. Degree of histological differentiation was then determined under the light microscope (BX41; Olympus Corporation, Tokyo, Japan) at x400 magnification.

VEGF-positive cells in tumor tissue were stained brown-yellow or brown in the cytoplasm. The tissue sections were scored according to the staining intensity and positive cell proportion. Staining intensity was scored as follows: Negative, 0 ; weakly-positive, 1 ; positive, 2 ; and strongly-positive, 3 . No positive cells was scored as 0 ; containing $<25 \%$ of positive cells as 1 , containing $25-50 \%$ of positive cells as 2 and containing $>50 \%$ of positive cells as 3 . For each section, the final score was calculated as the sum of the staining intensity and positive cells proportion, with a final score of 0-3 as VEGF-negative, and 3-6 as VEGF-positive.

MVD calculation. The tumor MVD was calculated by the method presented by Weidner with certain modifications (25). First, five fields with the highest blood vessels densities were identified at x100 magnification under a light microscope; microvessels were then counted on the monitor of a computer image analysis system (Image Pro Plus 4; Media Cybernetics, Rockville, MD, USA) under a light microscope at x200 magnification, and the mean microvessel number was calculated as the MVD value. No matter whether a tube was formed, any single EC or multiple ECs arranged compactly were assumed to be a blood vessel. When a tubular structure was not continuous phase, its branches were also viewed as a blood vessels. Cells that were difficult to distinguish or dimly stained, as well as thick-walled muscular vessels or lumen of $>50 \mu \mathrm{m}$ (equivalent to $\geq 1 \mathrm{~cm}$ at magnification, $\mathrm{x} 200$ ) were not counted.

Detection of EPCs/ECs in peripheral blood. For each patient, $6 \mathrm{ml}$ peripheral blood with added anticoagulant was collected, followed by determination of the number of EPCs and ECs by flow cytometry (BD Biosciences, Franklin Lakes, NJ, USA) (26). In brief, EPCs were defined as $\mathrm{CD} 34^{\text {bright }} \mathrm{CD} 133^{+} \mathrm{CD} 31^{+} \mathrm{CD} 45^{\mathrm{dim}}$ cells, and ECs were defined as CD $34^{\mathrm{dim}} \mathrm{CD} 133^{-} \mathrm{CD} 31^{\text {bright }} \mathrm{CD} 45$ cells, as described previously (24).

Statistical analysis. SPSS19.0 software (IBM Corp., Armonk, NY, USA) was used for statistical analysis. Measurement data were denoted as mean \pm standard deviation, and the nominal data were denoted as percentages. The difference in measurement data between two independent samples was determined using Student's t-test, and that between two sets of categorical data was determined using the $\chi^{2}$ test. The correlation between EPCs/ECs and VEGF/MVD was investigated by Spearman's correlation analysis. $\mathrm{P}<0.05$ was considered to indicate a statistically significant difference.

\section{Results}

Association between EPCs/ECs and clinicopathological factors in GC. The number of EPCs and ECs gradually increased in patients with GC between stages I and III, with stages II and III each have a significantly higher number of EPCs and ECs compared with stage I $(\mathrm{P}<0.05)$. The number of EPCs in stage IV patients was reduced, while there were significantly more ECs than in either stage I, II or III patients $(\mathrm{P}<0.05$; Figs. 1 and 2$)$.

There were significantly fewer EPCs in patients with GC with tumors that had not invaded into serosa compared with EPCs in patients with GC with tumors that had invaded into the serosa $(\mathrm{P}<0.01)$, while there were significantly more ECs in patients with tumors that had not invaded into serosa compared with ECs in patients with GC with tumors that had invaded into serosa $(\mathrm{P}<0.01)$. The number of EPCs in patients with distant metastasis was significantly smaller than that in patients without distant metastasis $(\mathrm{P}<0.01)$, while the number of ECs in patients with distant metastasis was significantly larger than that in patients without distant metastasis $(\mathrm{P}<0.01)$. There were significantly more EPCs and ECs in patients with lymph node metastasis compared with those in patients without lymph node metastasis $(\mathrm{P}<0.05)$. No significant association was observed between the EPC/EC ratio and either sex, age, tumor size or differentiation degree $(\mathrm{P}>0.05$; Table I).

Association between VEGF and clinicopathological factors in $G C$. VEGF expression was mainly observed in tumor cell cytoplasm, and also somewhat in the nuclei. VEGF was not expressed in the majority of normal gastric mucosal epithelia (Fig. 3A). Comparatively, VEGF-positive cells were identified in tumors in $66.67 \%$ of patients with GC (Fig. 3B).

VEGF-positive cells accounted for 44, 60, 80 and $87.5 \%$ in patients with GC at TNM stages I, II, III and IV, respectively, with significant differences between each other $(\mathrm{P}<0.05)$. VEGF-positive cells increased significantly from $27.27 \%$ in patients with GC with tumors that had not invaded into the serosa to $80.65 \%$ in patients with GC with tumors that had invaded into the serosa $(\mathrm{P}<0.01)$. The $\mathrm{VEGF}$ expression rate in patients with GC with lymph node metastasis was $90 \%$, which was significantly higher than that in patients without lymph node metastasis $(45.45 \%)(\mathrm{P}<0.01)$. VEGF expression level was not significantly associated with the age, sex, tumor size, histological grade or distant metastasis of patients $(\mathrm{P}>0.05)$ (Table I).

Association between VEGF and clinicopathological factors in $G C$. CD34 was expressed in the majority of capillaries. Areas with the highest CD34 density were mostly the leading edges infiltrated by tumor cells. The vascular endothelial cells were evenly stained in tumor tissues, and the new vessels were 

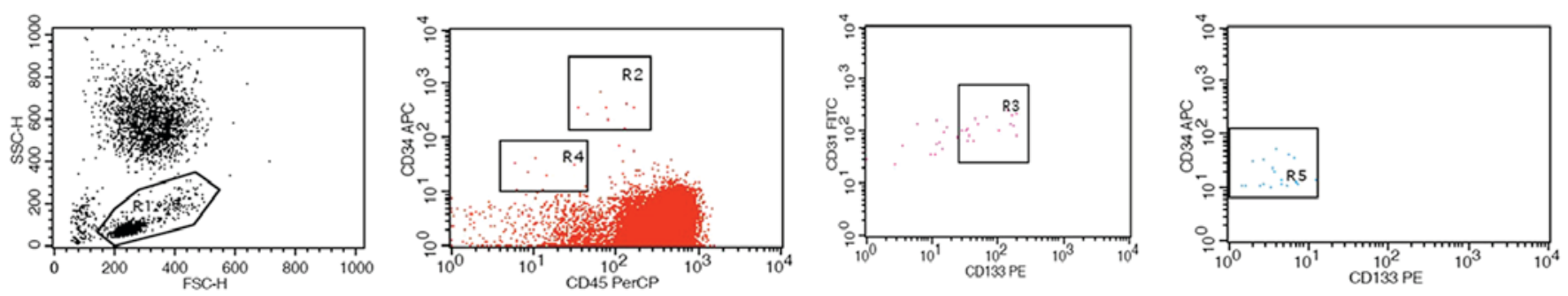

Figure 1. Plots of EPCs and ECs detected in patients with tumor-node-metastasis stage I gastric cancer by flow cytometry. R1, mononuclear cells; R2, $\mathrm{CD} 45^{\text {dim }} \mathrm{CD} 34^{\text {bright }}$ cells; $\mathrm{R} 3, \mathrm{CD} 45^{\mathrm{dim}} \mathrm{CD} 34^{\text {bright }} \mathrm{CD} 133^{+} \mathrm{CD} 31^{+}$cells $(\mathrm{EPCs}) ; \mathrm{R} 4, \mathrm{CD} 45^{-\mathrm{CD}} 34^{+}$cells; $\mathrm{R} 5, \mathrm{CD} 45^{-} \mathrm{CD} 34^{+} \mathrm{CD} 133^{-} \mathrm{CD} 31^{\text {bright }}$ cells $(\mathrm{EC}$ ); $\mathrm{EPC}$, endothelial progenitor cell; EC, mature endothelial cell; $\mathrm{CD}$, cluster of differentiation.
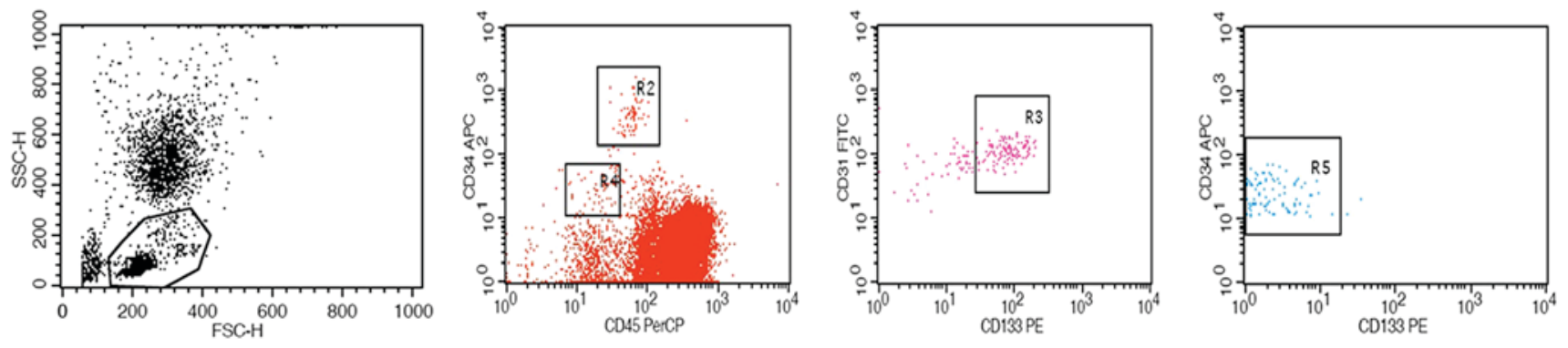

Figure 2. Plots of EPCs and ECs detected in patients with tumor-node-metastasis stage III gastric cancer by flow cytometry. R1, mononuclear cells; R2, CD45 ${ }^{\text {dim }} \mathrm{CD} 34^{\text {bright }}$ cells; R3, CD45 ${ }^{\text {dim }} \mathrm{CD} 34^{\text {bright }} \mathrm{CD} 133^{+} \mathrm{CD} 31^{+}$cells $(\mathrm{EPCs}) ; \mathrm{R} 4, \mathrm{CD} 45^{-} \mathrm{CD} 34^{+}$cells; $\mathrm{R} 5, \mathrm{CD} 45^{-\mathrm{CD}} 34^{+} \mathrm{CD} 133^{-} \mathrm{CD} 31^{\text {bright }}$ cells $(\mathrm{EC})$; $\mathrm{EPC}$, endothelial progenitor cell; EC, mature endothelial cell; $\mathrm{CD}$, cluster of differentiation.

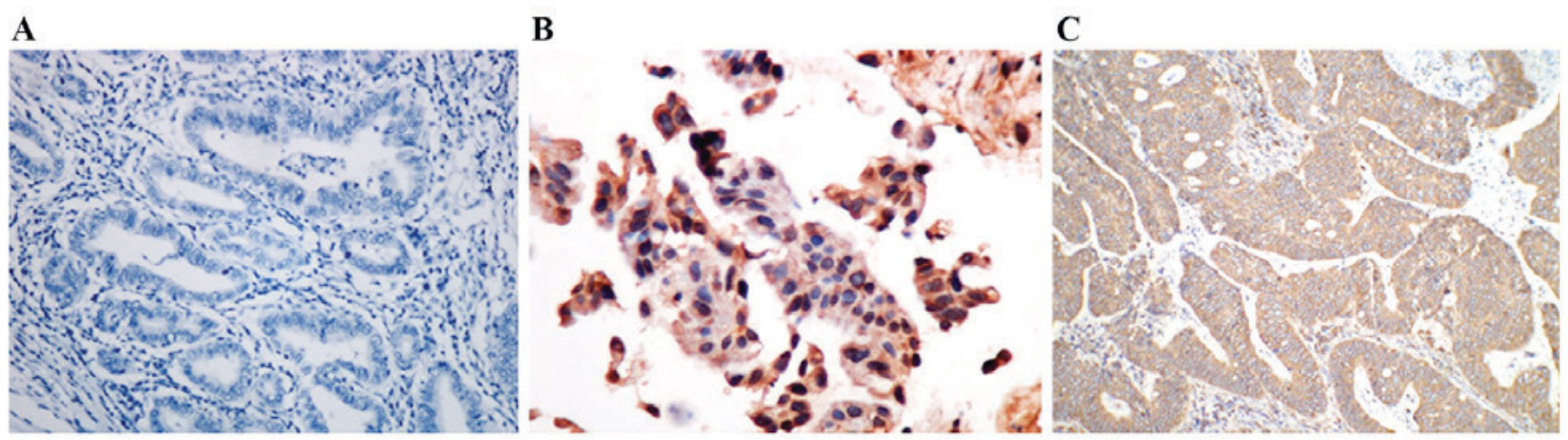

Figure 3. Expression of vascular endothelial growth factor in tumor tissues using immunohistochemical staining based on streptomycin avidin-peroxidase method (magnification, $\mathrm{x} 400$ ). (A) Normal tissues. (B) Tumor tissues. (C) Positive controls.

expanded, narrowed or deformative. Microvascular distribution was heterogeneous, with disordered branches, and the vascular endothelial cells had varied shapes. The MVD (34.48 \pm 5.96$)$ was significantly larger than that of normal gastric tissues adjacent to tumor tissues $(17.76 \pm 5.63)(\mathrm{P}<0.01$; Fig. 4A and $\mathrm{B})$. MVD was significantly associated with TNM stage, invasion depth and lymph node metastasis in GC $(\mathrm{P}<0.01$ or $\mathrm{P}<0.05)$, while not with the age, sex, tumor size or histological type of the patients $(\mathrm{P}>0.05$; Table I).

Correlation between EPCs/ECs and VEGF /MVD in gastric cancer tissues. Both the EPC and EC number were positively correlated with VEGF level in gastric cancer tissues $(\mathrm{P}<0.01)$, with correlation coefficients of 0.535 and 0.433 , respectively. The number of EPCs was positively correlated with MVD $(\mathrm{P}<0.05 ; \mathrm{r}=0.332)$, and the number of ECs was positively correlated with MVD $(\mathrm{P}<0.01 ; \mathrm{r}=0.669)$.

\section{Discussion}

The present study determined the numbers of EPCs and ECs in the peripheral blood, and also detected MVD distribution and VEGF expression in gastric tissues.

Although EPCs perform an important role in tumor angiogenesis, their role in gastric cancer angiogenesis remains unclear. Furthermore, there are few studies on EPCs in patient peripheral blood. Kim et al (27) reported no increase in the number of circulating EPCs in patients with cancer (including GC), although the plasma VEGF level was found to be elevated. However, a significant increase was found in EPC number during tumor angiogenesis (28). The present study revealed that the number of EPCs and ECs in patients with stage III GC was higher than the numbers in stage I and II patients. The number of EPCs in stage IV patients was reduced, while the number of ECs was significantly increased compared with 
Table I. Association between either EPCs/ECs, VEGF expression or MVD and clinicopathological factors in gastric cancer.

\begin{tabular}{|c|c|c|c|c|c|c|}
\hline \multirow[b]{2}{*}{$\begin{array}{l}\text { Clinicopathological } \\
\text { factors }\end{array}$} & \multirow[b]{2}{*}{ Patients, $\mathrm{n}$} & \multirow[b]{2}{*}{$\begin{array}{c}\text { EPCs/mononuclear } \\
\text { cells }\end{array}$} & \multirow[b]{2}{*}{$\begin{array}{c}\text { ECs/mononuclear } \\
\text { cells }\end{array}$} & \multicolumn{2}{|c|}{ VEGF expression } & \multirow[b]{2}{*}{ MVD } \\
\hline & & & & $\begin{array}{l}\text { VEGF }^{+} \\
(\mathrm{n}=28)\end{array}$ & $\begin{array}{l}\text { VEGF- } \\
(\mathrm{n}=14)\end{array}$ & \\
\hline Age, years & & & & $58.179 \pm 11.112$ & $56.643 \pm 10.043$ & \\
\hline$\leq 60$ & 32 & $0.038 \pm 0.030$ & $0.181 \pm 0.072$ & $22(68.75)$ & $10(31.25)$ & $33.5 \pm 6.0$ \\
\hline$>60$ & 10 & $0.030 \pm 0.017$ & $0.111 \pm 0.091$ & $6(60.00)$ & $4(40.00)$ & $30.1 \pm 4.5$ \\
\hline \multicolumn{7}{|l|}{ Sex } \\
\hline Male & 28 & $0.041 \pm 0.024$ & $0.146 \pm 0.084$ & $18(64.29)$ & $10(35.71)$ & $30.7 \pm 4.9$ \\
\hline Female & 14 & $0.047 \pm 0.001$ & $0.133 \pm 0.002$ & $10(71.43)$ & $4(28.57)$ & $31.2 \pm 4.8$ \\
\hline \multicolumn{7}{|l|}{ Tumor size, $\mathrm{cm}$} \\
\hline$\leq 5$ & 29 & $0.029 \pm 0.022$ & $0.138 \pm 0.090$ & $20(68.97)$ & $9(31.03)$ & $31.5 \pm 6.4$ \\
\hline$>5$ & 13 & $0.056 \pm 0.030$ & $0.198 \pm 0.031$ & $8(61.54)$ & $5(38.46)$ & $29.7 \pm 5.2$ \\
\hline \multicolumn{7}{|l|}{ Histological type } \\
\hline Highly differentiated & 14 & $0.032 \pm 0.020$ & $0.110 \pm 0.059$ & $8(57.14)$ & $6(42.86)$ & $31.0 \pm 7.5$ \\
\hline Moderately differentiated & 15 & $0.043 \pm 0.027$ & $0.141 \pm 0.071$ & $10(66.67)$ & $5(33.33)$ & $29.8 \pm 4.5$ \\
\hline Poorly differentiated & 13 & $0.031 \pm 0.032$ & $0.272 \pm 0.077$ & $10(76.92)$ & $3(23.08)$ & $30.6 \pm 5.1$ \\
\hline \multicolumn{7}{|l|}{ Invasion depth } \\
\hline Sub-serosa & 11 & $0.057 \pm 0.020$ & $0.120 \pm 0.002$ & $3(27.27)$ & $8(72.73)$ & $29.4 \pm 4.2$ \\
\hline Serosa & 31 & $0.030 \pm 0.021^{\mathrm{a}}$ & $0.150 \pm 0.088^{\mathrm{a}}$ & $25(80.65)^{\mathrm{a}}$ & $6(19.35)$ & $33.8 \pm 4.4^{\mathrm{b}}$ \\
\hline \multicolumn{7}{|l|}{ Lymph node metastasis } \\
\hline No & 22 & $0.030 \pm 0.023$ & $0.133 \pm 0.067$ & $10(45.45)$ & $12(54.55)$ & $25.8 \pm 5.7$ \\
\hline Yes & 20 & $0.040 \pm 0.020^{\mathrm{b}}$ & $0.181 \pm 0.070^{\mathrm{b}}$ & $18(90.00)^{\mathrm{a}}$ & $2(10.00)$ & $32.2 \pm 4.1^{\mathrm{a}}$ \\
\hline \multicolumn{7}{|l|}{ Distant metastasis } \\
\hline No & 34 & $0.040 \pm 0.026$ & $0.136 \pm 0.072$ & $22(64.71)$ & $12(35.29)$ & $30.3 \pm 7.5$ \\
\hline Yes & 8 & $0.011 \pm 0.0002^{\mathrm{a}}$ & $0.297 \pm 0.002^{\mathrm{a}}$ & $6(75.00)$ & $2(25.00)$ & $32.4 \pm 8.9$ \\
\hline \multicolumn{7}{|l|}{ TNM staging } \\
\hline I & 9 & $0.023 \pm 0.010$ & $0.085 \pm 0.058$ & $4(44.44)$ & $5(55.56)$ & $28.1 \pm 4.7$ \\
\hline II & 15 & $0.043 \pm 0.019^{\mathrm{b}}$ & $0.168 \pm 0.036^{\mathrm{b}}$ & $9(60.00)^{\mathrm{b}}$ & $6(40.00)$ & $29.4 \pm 4.6^{\mathrm{a}}$ \\
\hline III & 10 & $0.049 \pm 0.039^{b}$ & $0.142 \pm 0.107^{\mathrm{b}}$ & $8(80.00)^{\mathrm{b}}$ & $2(20.00)$ & $36.9 \pm 4.3^{\mathrm{a}}$ \\
\hline IV & 8 & $0.011 \pm 0.001$ & $0.298 \pm 0.001^{\mathrm{b}}$ & $7(87.50)^{\mathrm{b}}$ & $1(12.50)$ & $38.8 \pm 4.0^{\mathrm{a}}$ \\
\hline
\end{tabular}

${ }^{\mathrm{a}} \mathrm{P}<0.01 ;{ }^{\mathrm{b}} \mathrm{P}<0.05$. All data are presented as $\mathrm{n}(\%)$ or mean \pm standard deviation. EPC, endothelial progenitor cell; EC, mature endothelial cell; VEGF, vascular endothelial growth factor; MVD, microvessel density; TNM, tumor-node-metastasis.
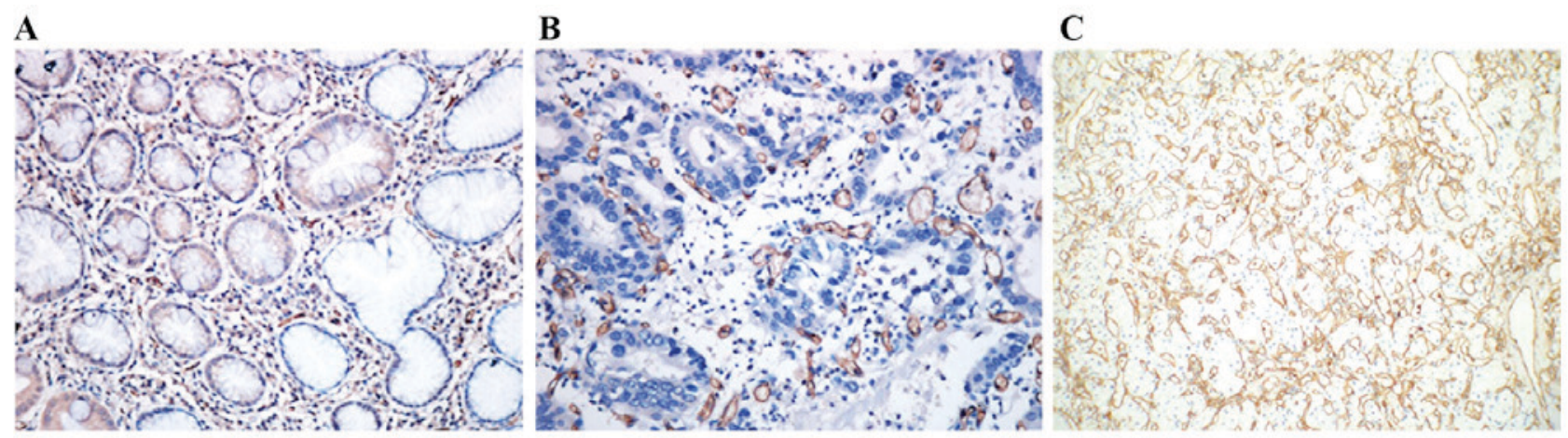

Figure 4. Expression of marker cluster of differentiation 34 in tumor tissues for calculation of microvessel density using immunohistochemical staining based on the streptomycin avidin-peroxidase method (magnification, x400). (A) Normal tissues. (B) Tumor tissues. (C) Positive controls.

those in either stage I, II or III patients, which is consistent with our previous findings (29). Furthermore, the number of
EPCs decreased in patients with tumors that had not invaded into the serosa or in those without distant metastasis compared 
with that in those patients with tumors that had penetrated into the serosa or with distant metastasis EPCs, while the number of ECs increased; this is consistent with previous findings that ECs are involved in the invasion of tumors into the serosa or in an angiogenesis occurring during a distant metastasis (30), not EPCs in angiogenesis (31). The number of EPCs and ECs in patients with lymph node metastasis was significantly increased compared with that in patients without lymph node metastasis, indicating that EPCs may be involved in GC lymph node metastasis, which requires validation. In addition, invasion of tumors into the serosa and/or distant metastasis was observed in the majority of patients with stage III and/or stage IV GC. Therefore, considering the aforementioned factors, it was hypothesized that EPCs are involved in angiogenesis at stages I and II, ECs and EPCs are involved in angiogenesis at stage III, and ECs may be the main cell type involved in angiogenesis at stage IV. The role of EPCs was found to vary following release into the blood and differentiation into ECs at different clinical stages of GC, and EPCs were also found to be involved in angiogenesis in varied ways.

In the present study, it was also observed that EPCs are found less in the peripheral blood of patients with stage IV GC compared with other stages, and thus, it was speculated that EPCs are more likely to gather around the tumor tissues to differentiate into ECs. It is currently known that recruitment of EPCs is closely associated with hypoxia, angiogenesis-associated factors and cell adhesion molecules (32). Studies using embryonic EPC tumor angiogenesis show higher MVD around the tumor and more EPCs homing to the tumor surroundings. EPC adhesion receptors associated with vascular endothelial adhesion molecules and laminin are highly expressed in the tumor periphery. As solid tumors grow, a relative hypoxic microenvironment is produced, promoting the secretion of growth factors, including VEGF and platelet-derived growth factor-BB, which promote the activation of EPCs and mobilization in the bone marrow, and then migrate into the ischemic tumor tissues (33). In addition, these factors also activate matrix metalloproteinases (MMPs), particularly MMP-9, inducing the release of a soluble kit ligand, accordingly facilitating the proliferation and emigration of EPCs from the bone marrow microenvironment (34). Thus, it is inferred that the decrease in EPCs in the peripheral blood of patients with stage IV GC is possibly due to an increased number of EPCs gathering around the tumors.

In the present study, VEGF expression was found to be significantly associated with MVD, TNM stage, invasion depth and lymph node metastasis in GC, while not with age, sex, histological type and tumor size, which is consistent with previous data (35). Furthermore, VEGF was positively associated with either EPC or EC level, indicating that VEGF, as a major angiogenesis regulator, promotes the involvement of EPCs in GC occurrence and development. EPC or EC levels, VEGF expression and MVD value are associated with angiogenesis, tumor growth, invasion and metastasis in GC.

EPCs have demonstrated their promising value as tumor diagnosis markers in renal cell carcinoma (36) and lung adenocarcinoma (37). It has been found that adrenomedullin receptor antagonists achieve their targeted therapy of pancreatic and kidney tumors in mice via inhibition of the mobilization of tumor endothelial cells and EPCs (38). As more becomes known about EPCs and angiogenesis-associated angiogenic factors, endogenous angiogenesis inhibitory factors and synthetic exogenous angiogenesis inhibitors, angiogenesis inhibition therapy may be a promising anticancer treatment. Therefore, a full understanding of the important role of EPCs in the angiogenesis of GC occurrence, development and metastasis will provide a novel insight in anti-angiogenic therapy against GC. Our future studies will investigate factors effecting the mobilization, migration and differentiation of EPCs at different clinical stages.

\section{Acknowledgements}

The present study was supported by the Shanghai Pudong New Area Health and Family Planning Commission Project (PW2015A16), the Shanghai Pudong New Area Health and Family Planning Commission Project(PW2015A-18), the Academic Leader Training Program of Pudong Health Bureau of Shanghai (PWRd2014-02) and the Shanghai Sailing Program (15YF1410800).

\section{References}

1. Rugge M, Fassan M and Graham DY: Epidemiology of gastric cancer. In: Gastric Cancer. Strong V (ed). Springer, Cham, pp23-34, 2015.

2. Chen W, Zheng R, Baade PD, Zhang S, Zeng H, Bray F, Jemal A, $\mathrm{Yu}$ XQ and He J: Cancer statistics in China, 2015. CA Cancer J Clin 66: 115-132, 2016.

3. Folkman J: Tumor angiogenesis: Therapeutic implications. N Engl J Med 285: 1182-1186, 1971.

4. Asahara T, Murohara T, Sullivan A, Silver M, van der Zee R, Li T, Witzenbichler B, Schatteman G and Isner JM: Isolation of putative progenitor endothelial cells for angiogenesis. Science 275: 964-967, 1997.

5. Basile DP and Yoder MC: Circulating and tissue resident endothelial progenitor cells. J Cell Physiol 229: 10-16, 2014.

6. Ishige-Wada M, Kwon SM, Eguchi M, Hozumi K, Iwaguro H, Matsumoto T, Fukuda N, Mugishima H, Masuda H and Asahara T: Jagged-1 signaling in the bone marrow microenvironment promotes endothelial progenitor cell expansion and commitment of $\mathrm{CD}_{133^{+}}$human cord blood cells for postnatal vasculogenesis. PLoS One 11: e0166660, 2016.

7. Salven P, Mustjoki S, Alitalo R, Alitalo K and Rafii S: VEGFR-3 and CD133 identify a population of CD $34^{+}$lymphatic/vascular endothelial precursor cells. Blood 101: 168-172, 2003.

8. Folkman J, Browder T and Palmblad J: Angiogenesis research: Guidelines for translation to clinical application. Thromb Haemost 86: 23-33, 2001.

9. Koch S, van Meeteren LA, Morin E, Testini C, Weström S, Björkelund H, Le Jan S, Adler J, Berger P and Claesson-Welsh L: NRP1 presented in trans to the endothelium arrests VEGFR2 endocytosis, preventing angiogenic signaling and tumor initiation. Dev Cell 28: 633-646, 2014.

10. Kushner EJ and Bautch VL: Building blood vessels in development and disease. Curr Opin Hematol 20: 231-236, 2013.

11. Szala S and Jarosz M: Tumor blood vessels. Postepy Hig Med Dosw (Online) 65: 437-446, 2011 (In Polish).

12. Ferrara N and Davis-Smyth T: The biology of vascular endothelial growth factor. Endocr Rev 18: 4-25, 1997.

13. Olson TA, Mohanraj D, Carson LF and Ramakrishnan S: Vascular permeability factor gene expression in normal and neoplastic human ovaries. Cancer Res 54: 276-280, 1994.

14. Brown LF, Berse B, Jackman RW, Tognazzi K, Manseau EJ, Senger DR and Dvorak HF: Expression of vascular permeability factor (vascular endothelial growth factor) and its receptors in adenocarcinomas of the gastrointestinal tract. Cancer Res 53: 4727-4735, 1993.

15. Joseph IB, Nelson JB, Denmeade SR and Isaacs JT: Androgens regulate vascular endothelial growth factor content in normal and malignant prostatic tissue. Clin Cancer Res 3: 2507-2511, 1997.

16. Takahashi Y, Kitadai Y, Bucana CD, Cleary KR and Ellis LM: Expression of vascular endothelial growth factor and its receptor, KDR, correlates with vascularity, metastasis, and proliferation of human colon cancer. Cancer Res 55: 3964-3968, 1995. 
17. Salven P, Ruotsalainen T, Mattson $\mathrm{K}$ and Joensuu H: High pre-treatment serum level of vascular endothelial growth factor (VEGF) is associated with poor outcome in small-cell lung cancer. Int J Cancer 79: 144-146, 1998.

18. Weidner N: Intratumor microvessel density as a prognostic factor in cancer. Am J Pathol 147: 9-19, 1995.

19. Joo HJ, Oh DK, Kim YS, Lee KB and Kim SJ: Increased expression of caveolin-1 and microvessel density correlates with metastasis and poor prognosis in clear cell renal cell carcinoma. BJU Int 93: 291-296, 2004.

20. Cavallaro U and Christofori G: Molecular mechanisms of tumor angiogenesis and tumor progression. J Neurooncol 50: 63-70, 2000.

21. Erenoglu C, Akin ML, Uluutku H, Tezcan L, Yildirim S and Batkin A: Angiogenesis predicts poor prognosis in gastric carcinoma. Dig Surg 17: 581-586, 2000.

22. Kido S, Kitadai Y, Hattori N, Haruma K, Kido T, Ohta M, Tanaka S, Yoshihara M, Sumii K, Ohmoto Y and Chayama K: Interleukin 8 and vascular endothelial growth factor-prognostic factors in human gastric carcinomas? Eur J Cancer 37: 1482-1487, 2001.

23. Wittekind C, Compton CC, Greene FL and Sobin LH: TNM residual tumor classification revisited. Cancer 94: 2511-2516, 2002.

24. An FQ, Matsuda M, Fujii H and Matsumoto Y: Expression of vascular endothelial growth factor in surgical specimens of hepatocellular carcinoma. J Cancer Res Clin Oncol 126: 153-160, 2000.

25. Weidner N: Intratumor microvessel density as a prognostic factor in cancer. Am J Pathol 147: 9-19, 1995.

26. Duda DG, Cohen KS, Scadden DT and Jain RK: A protocol for phenotypic detection and enumeration of circulating endothelial cells and circulating progenitor cells in human blood. Nat Protoc 2: 805-810, 2007.

27. Kim HK, Song KS, Kim HO, Chung JH, Lee KR, Lee YJ, Lee DH, Lee ES, Kim HK, Ryu KW and Bae JM: Circulating numbers of endothelial progenitor cells in patients with gastric and breast cancer. Cancer Lett 198: 83-88, 2003.

28. Ahn JB, Rha SY, Shin SJ, Jeung HC, Kim TS, Zhang X, Park KH, Noh SH, Roh JK and Chung HC: Circulating endothelial progenitor cells (EPC) for tumor vasculogenesis in gastric cancer patients. Cancer Lett 288: 124-132, 2010.

29. Li BJ, Cao FF, Xu LM, Nie ZH, Wei TX, Zhang LG and Zhang DH: Endothelial progenitor cells and endothelial cells in gastric cancer. Shanghai Med J 34: 467-469, 2011 (In Chinese).
30. Folkman J, Browder T and Palmblad J: Angiogenesis research: Guidelines for translation to clinical application. Thromb Haemost 86: 23-33, 2001.

31. Asahara T, Murohara T, Sullivan A, Silver M, van der Zee R, Li T, Witzenbichler B, Schatteman G and Isner JM: Isolation of putative progenitor endothelial cells for angiogenesis. Science 275: 964-967, 1997.

32. Jin H, Aiyer A, Su J, Borgstrom P, Stupack D, Friedlander M and Varner J: A homing mechanism for bone marrow-derived progenitor cell recruitment to the neovasculature. J Clin Invest 116: 652-662, 2006.

33. Francavilla C, Maddaluno L and Cavallaro U: The functional role of cell adhesion molecules in tumor angiogenesis. Semin Cancer Biol 19: 298-309, 2009.

34. Chakroborty D, Sarkar C, Basu B, Dasgupta PS and Basu S: Catecholamines regulate tumor angiogenesis. Cancer Res 69: 3727-3730, 2009.

35. Zheng H, Takahashi H, Murai Y, Cui Z, Nomoto K, Niwa H, Tsuneyama K and Takano Y: Expressions of MMP-2, MMP-9 and VEGF are closely linked to growth, invasion, metastasis and angiogenesis of gastric carcinoma. Anticancer Res, 26: 3579-3583, 2006.

36. Yang B, Gu W, Peng B, Xu Y, Liu M, Che J, Geng J and Zheng J: High level of circulating endothelial progenitor cells positively correlates with serum vascular endothelial growth factor in patients with renal cell carcinoma. J Urol 188: 2055-2061, 2012.

37. Maeda R, Ishii G, Ito M, Hishida T, Yoshida J, Nishimura M, Haga H, Nagai K and Ochiai A: Number of circulating endothelial progenitor cells and intratumoral microvessel density in non-small cell lung cancer patients: Differences in angiogenic status between adenocarcinoma histologic subtypes. J Thorac Oncol 7: 503-511, 2012.

38. Tsuchiya K, Hida K, Hida Y, Muraki C, Ohga N, Akino T, Kondo T, Miseki T, Nakagawa K, Shindoh M, et al: Adrenomedullin antagonist suppresses tumor formation in renal cell carcinoma through inhibitory effects on tumor endothelial cells and endothelial progenitor mobilization. Int J Oncol 36: 1379-1386, 2010.

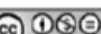

This work is licensed under a Creative Common Attribution-NonCommercial-NoDerivatives 4.0 International (CC BY-NC-ND 4.0) License. 